\title{
Unpacking future climate extremes and their sectoral implications in western Nepal
}

\author{
Dipesh Chapagain $^{1}$ D $\cdot$ Sanita Dhaubanjar ${ }^{2} \cdot$ Luna Bharati $^{1,2}$
}

Received: 22 April 2021 / Accepted: 3 September 2021/ Published online: 19 September 2021

(C) The Author(s) 2021

\begin{abstract}
Existing climate projections and impact assessments in Nepal only consider a limited number of generic climate indices such as means. Few studies have explored climate extremes and their sectoral implications. This study evaluates future scenarios of extreme climate indices from the list of the Expert Team on Sector-specific Climate Indices (ET$\mathrm{SCI}$ ) and their sectoral implications in the Karnali Basin in western Nepal. First, future projections of 26 climate indices relevant to six climate-sensitive sectors in Karnali are made for the near (2021-2045), mid (2046-2070), and far (2071-2095) future for lowand high-emission scenarios (RCP4.5 and RCP8.5, respectively) using bias-corrected ensembles of 19 regional climate models from the COordinated Regional Downscaling EXperiment for South Asia (CORDEX-SA). Second, a qualitative analysis based on expert interviews and a literature review on the impact of the projected climate extremes on the climate-sensitive sectors is undertaken. Both the temperature and precipitation patterns are projected to deviate significantly from the historical reference already from the near future with increased occurrences of extreme events. Winter in the highlands is expected to become warmer and dryer. The hot and wet tropical summer in the lowlands will become hotter with longer warm spells and fewer cold days. Low-intensity precipitation events will decline, but the magnitude and frequency of extreme precipitation events will increase. The compounding effects of the increase in extreme temperature and precipitation events will have largely negative implications for the six climate-sensitive sectors considered here.
\end{abstract}

Keywords Climate extremes $\cdot$ ET-SCI $\cdot$ Climate change impacts $\cdot$ ClimPACT2 $\cdot$ Karnali $\cdot$ Nepal

Dipesh Chapagain

dipesh@uni-bonn.de

1 Center for Development Research (ZEF), University of Bonn, Bonn, Germany

2 International Water Management Institute (IWMI), Kathmandu, Nepal 


\section{Introduction}

Extreme weather and climate events linked with anthropogenic climate change have become more frequent and intense around the world since the 1950s (IPCC 2013, 2021). Furthermore, the changes in extremes will be larger with projected global warming (IPCC 2021). Nepal is one of the most impacted countries by extreme weather events and is at high risk due to its high vulnerability and low readiness (ND-GAIN 2018; Eckstein et al. 2021). Climatic disaster incidences have been increasing in recent decades, which is also the leading cause of natural disaster mortality in Nepal (Aksha et al. 2018). Warmer temperatures have intensified the risk of vector-borne diseases and epidemics (Thakur et al. 2012; Dhimal et al. 2015). Agricultural productivity losses due to changing climate cause severe food insecurity and have a detrimental impact on the country's overall economy (Chalise et al. 2017; Bocchiola et al. 2019). Therefore, a better understanding of the behavior of extreme values is necessary, particularly to understand its sectoral implications and plan for adaptation (ETCCDI 2009).

The characterization of climate extremes and their evolution over time can be made using standardized extreme indices (ETCCDI 2009). In 1999, the Expert Team on Climate Change Detection and Indices (ETCCDI) formulated a set of indices to detect and characterize the nature of climate extremes in terms of frequency, amplitude, and persistence. Subsequently, the Expert Team on Sector-specific Climate Indices (ET-SCI) was introduced in 2011 to expand the generic ETCCDI indices to more comprehensive and sector-specific climate indices (ET-SCI 2016). The team noted however that the sectorial practices and climate characteristics vary across the region and recommend the customization of the ET-SCI indices to fit the study location.

Past studies have analyzed historical extreme climate indices trends and observed a rise in heavy precipitation events and hot extremes across Nepal (Khatiwada et al. 2016; Karki et al. 2017, 2019; Bohlinger and Sorteberg 2018; Talchabhadel et al. 2018; Pokharel et al. 2019; Sharma et al. 2020; Poudel et al. 2020). For example, Karki et al. (2019) observed a rising trend for warm days (13 days/decade) and nights (4 days/decade), but the cold days and nights are decreasing (6 days/decade). The high-intensity (> $300 \mathrm{~mm} /$ day) precipitation started becoming more frequent since 2000, which was not common earlier (Pokharel et al. 2019). DHM (2017) observed an increasing trend in the number of rainy days, especially in the northern region. Nevertheless, only a few studies have addressed the future climate extremes, and even fewer have explored their implications for various sectors (Rajbhandari et al. 2017; MoFE 2019; Pokharel et al. 2019; Dahal et al. 2020; Singh et al. 2021). Moreover, these studies are mostly based on means and a small subset of the old and generic ETCCDI indices.

The location-specific climate responses due to the heterogeneous geographic and climatic conditions within small spatial extents in Nepal demand future climate projections and impact assessments on a finer scale (Rajbhandari et al. 2017; Dhaubanjar et al. 2020). The faster increase in extreme precipitation in western Nepal compared to other parts of the country highlights the necessity of future climate assessments in this region (Bohlinger and Sorteberg 2018; Talchabhadel et al. 2018; Pokharel et al. 2019). However, basin-scale climate assessments are mostly concentrated in eastern Nepal (Bharati et al. 2014, 2019; Devkota and Gyawali 2015; Nepal 2016) as opposed to western Nepal (Dahal et al. 2020; Pandey et al. 2020).

Regional climate models (RCMs) are designed for a specific region and are richer in spatial and temporal detail to better simulate topography-influenced phenomena and extremes (Flato et al. 2013). Therefore, RCMs are more suitable than global climate models (GCMs) for 
climate projections in countries with diverse and steep terrain, such as Nepal (Dhaubanjar et al. 2020). Multi-modal ensembles are recommended for climate impact assessments (Knutti et al. 2010). However, most climate projections and impact assessments in Nepal have used a limited number of GCMs. The development of RCMs specifically for South Asia remains a relatively new initiative by the COordinated Regional Downscaling EXperiment for South Asia (CORDEX-SA) (Sanjay et al. 2017) to generate dynamically downscaled projections for the region. Dhaubanjar et al. (2020) presented one of the first and the most comprehensive studies that utilized all available 19 RCMs in CORDEX-SA to generate application-specific multi-model ensemble climate projections for the Karnali Basin. However, the scope of Dhaubanjar et al. (2020) was limited to ensemble generation.

Leveraging the bias-corrected and application-specific RCM ensemble projections generated by Dhaubanjar et al. (2020), this study presents the first assessment of the ET-SCI indices to understanding changes in future climate extremes and their sectoral implications in Karnali. We first identify sector-relevant climate indices for Karnali. Second, we project future scenarios of these climate indices. A total of 26 climate indices were selected based on an index evaluation, expert consultation, and literature review. Their trends were projected for three future timeframes, i.e., near (2021-2045), mid (2046-2070), and far (2071-2095) future, for two emission scenarios (RCP4.5 and RCP8.5). Unlike a pure climate projection study, we finally analyzed the potential implications of the projected index trends in six key climatesensitive sectors in the region based on expert interviews and literature review.

\section{Methodology}

\subsection{Study area}

Covering an area of $49,889 \mathrm{~km}^{2}$ with an elevation ranging from 142 to $8143 \mathrm{~m}$ along a southnorth transect in western Nepal, the Karnali River Basin (Fig. 1), also referred to as Karnali in this paper, is at the headwaters of the Ganges Basin (Pandey et al. 2020). Area-wise, Karnali is the biggest river basin in Nepal, yet it is the least developed and most food-insecure region in the country (UN-WFP 2014). This region has the highest poverty rate in Nepal, with every second person being multidimensionally poor (NPC 2018). The highlands in Karnali are relatively water-poor regions in Nepal (Panthi et al. 2018). The indigenous communities rely on natural springs as their primary source of water for drinking and irrigation and are highly vulnerable to changes in precipitation (Matheswaran et al. 2019). The southern lowlands are prone to disasters, such as floods and droughts, and the northern highlands experience landslides and flash floods.

Western Nepal has over 336,927 ha of agricultural land, of which nearly $49 \%$ remains to be irrigated (CBS 2020). Similarly, Karnali has a run-off river-type hydropower potential of 15,660 MW because of the major rivers and steep slopes in the highlands (Jha 2010). Nearly 127 projects, including some of the country's largest hydropower and irrigation projects, are in various stages of development in this basin (IWMI 2018). Karnali is also a biodiversity hotspot, with approximately $14 \%$ of the area under protection, and is comprised of four national parks, one wildlife reserve, one hunting reserve, two buffer zones, and three Ramsar sites (Khatiwada and Pandey 2019; DNPWC 2020). Overall, Karnali remains largely rural, with sparse communities relying heavily on nature-based livelihoods, rich biodiversity and natural resources, and untapped hydropower potential spread throughout the basin. These 


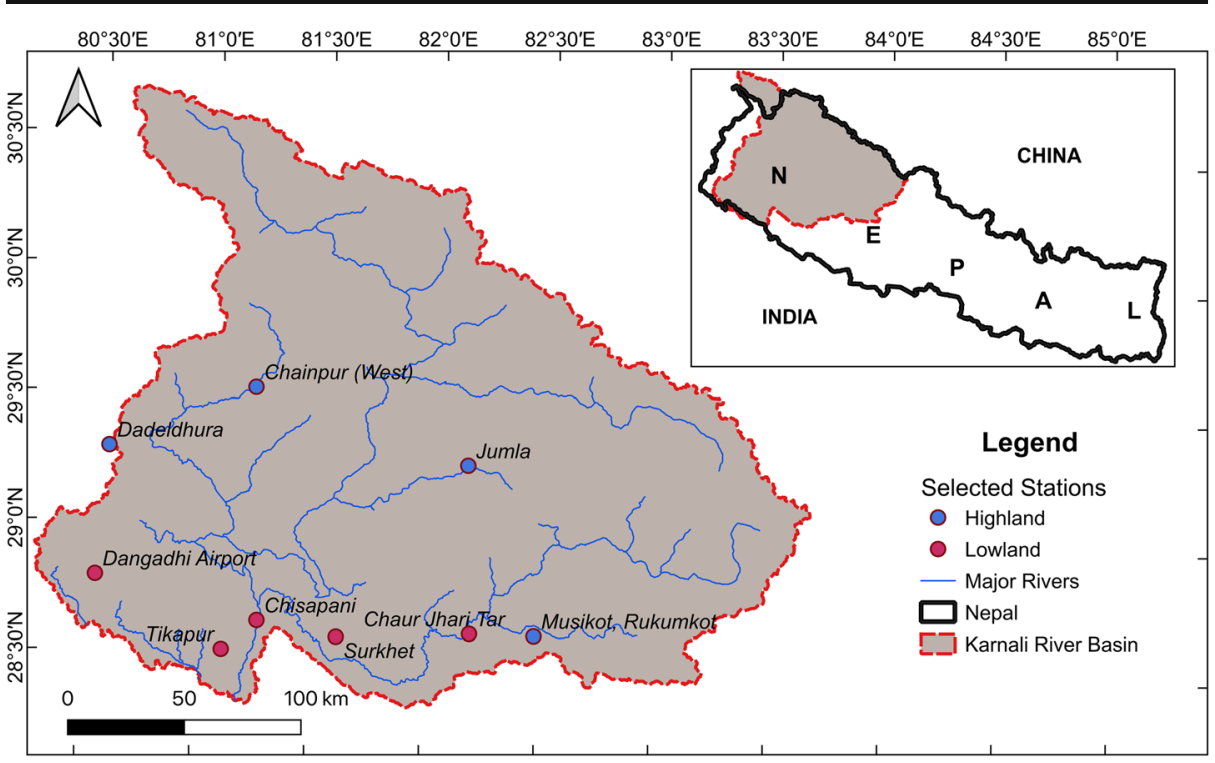

Fig. 1 Map of the Karnali River Basin and locations of the meteorological stations selected for this study

characteristics of Karnali provide a suitable background for a multi-sectoral climate impact assessment on a relatively pristine basin.

\subsection{Bias-corrected ensemble projection}

An overview of our research design and methodology is presented in Fig. 2. We started with the ensemble projections developed by Dhaubanjar et al. (2020) for nine meteorological stations based on 19 RCMs in CORDEX-SA. Dhaubanjar et al. (2020) first use quantile mapping to bias-correct the $19 \mathrm{RCMs}$ and then apply the climate futures framework (Clarke et al. 2011) to generate application-specific projections for climate impact assessment (see Table S1 in electronic supplementary materials (ESM) for details on the stations and Table S2 for details on the RCMs). Ensemble projections are available for three future risk scenarios (low risk, consensus, and high risk) for long-term water management of which we only consider the consensus case, i.e., projections based on an ensemble of RCMs that show consensus in the magnitudes of change in precipitation and temperature. More specifically, we use the consensus case data from Dhaubanjar et al. (2020) for the historical (1981-2005) period and three future timeframes (near, 2021-2045; mid, 2046-2070; and far, 2071-2095) under two global representative concentration pathways (RCP4.5 and RCP8.5). Details on data quality control, bias correction using the quantile-mapping approach, evaluation of the bias correction performance, and generation of the climate ensembles are provided in Dhaubanjar et al. (2020).

\subsection{Evaluation of ET-SCI indices}

The ClimPACT2 program, developed by ET-SCI (2016) in the R programming language, was used to evaluate 34 core and 29 non-core ET-SCI indices at both annual and monthly timesteps. For each station, we prepared single time-series combining bias-corrected historical 


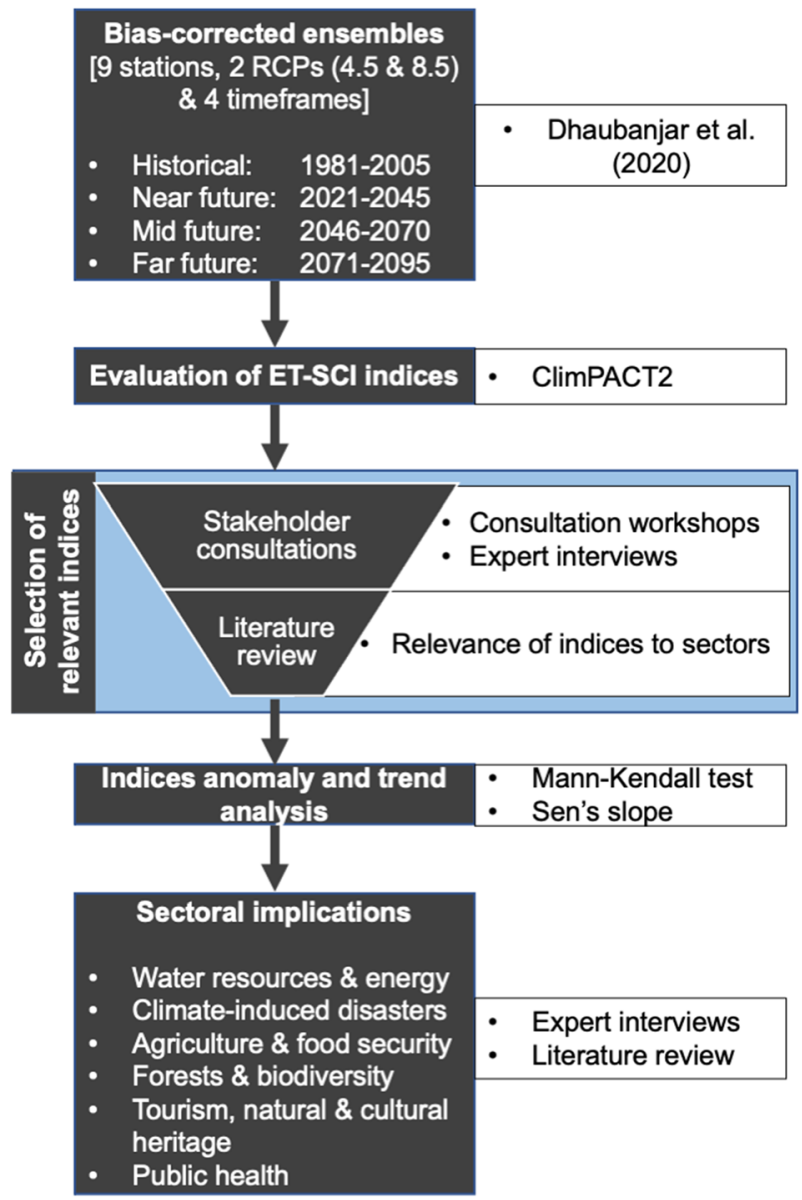

Fig. 2 Methodological framework for unpacking future climate extremes in Karnali and their sectoral implications

(1981-2005) and future (2006-2100) time series for each of the six RCM ensembles as inputs to ClimPACT2. The bias-corrected historical data for 1981-2005 were therefore inserted as the base period for the evaluation of all the percentile-based indices. To allow for cross-comparisons with global studies, default values were used for indices with absolute thresholds. The evaluated index values were then sliced for the respective historical and future timeframes.

\subsection{Selection of sector-relevant indices}

The National Adaptation Plan (NAP) process in Nepal was initiated in 2015 to determine medium- and long-term adaptation needs, which identified seven sectors as the most climatesensitive in Nepal (MoPE 2017). These sectors include (i) water resources and energy, (ii) climate-induced disasters, (iii) agriculture and food security, (iv) forests and biodiversity, (v) tourism and natural and cultural heritage, (vi) public health, and (vii) urban settlements and infrastructure. We considered six of these sectors in this study to identify the relevant indices 
and study the sectoral implications in Karnali. Urban settlement and infrastructure was not considered as a separate sector here because Karnali is a largely rural region.

To determine the relevance of the ET-SCI indices to the climate-sensitive sectors, we gathered qualitative inputs from stakeholders in two rounds of consultations. We conducted a hands-on workshop with 39 participants, largely practitioners and policymakers from all sectors, as shown in Fig. S1 in ESM. Participants engaged in group discussions followed by a survey asking for their perception of climate characteristics or types of extreme climate that posed risks to their sectors. Note that the climate indices were not directly referenced in the questionnaire; instead, real-life examples were presented to make participants consider what-if climate scenarios and their impacts on their sectors. Very few participants were able to consider climate characteristics beyond means and minimum and maximum values, providing a limited basis to consider the specialized ET-SCI indices.

To further unpack the stakeholder's perspectives, we followed up with more targeted keyexpert interviews. We explicitly discussed the relevance of the ET-SCI indices with at least two experts from each sector (the list of consulted experts is given in Table S3). In addition, we reviewed the literature to identify the reported relationship between the climate characteristics and the sectoral impacts. Finally, considering the inputs from the stakeholders and literature, the type of indices and thresholds used, and our experiences working in Karnali, we selected 26 of the ET-SCI indices for this study. We grouped the indices by type into mean-based, absolute-value-based, percentile-based, threshold-based, and duration-based indices that characterize the average and extreme statistical features of the climate data. Details of the selected indices are summarized in Table 1.

\subsection{Index anomaly and trend analyses}

For the selected indices, we analyzed the projected index trend and their anomalies to evaluate the spatio-temporal variation across the regions. The widely used non-parametric MannKendall test (Mann 1945; Kendall 1975) was used to investigate the trend significance for the near-, mid-, and far-future timeframes. The trend value was estimated using Sen's slope (Sen 1968) method. Only trend values significant at 95\% confidence interval $(p<0.05)$ are reported in this paper unless otherwise stated. Nevertheless, the count of the trend significance cases for each index is summarized in Fig. 3. The index anomaly or the projected change from the historical average was calculated by subtracting the mean of the bias-corrected historical value from the equivalent projected future value. To capture the altitudinal difference, the five stations located below an altitude of $1000 \mathrm{~m}$ were grouped as the lowland stations, and the four stations above an altitude of $1000 \mathrm{~m}$ were grouped as the highland stations. Trends across the four seasons (pre-monsoon, March-May; monsoon, June-September; post-monsoon, October-November; and winter, December-February) were further assessed for relevant indices based on the monthly values.

\subsection{Characterization of sectoral implications}

The projection results of the selected indices were shared with experts from all of the studied sectors in the third round of expert interviews. The experts were asked to share their opinions concerning the potential implications of the projected index trends on their sectors. Received inputs were supplemented by a literature review to characterize the potential implications of the projected changes to the six sectors. 
Table 1 List of selected climate indices for this study (adapted from ET-SCI (2016))

\begin{tabular}{|c|c|c|c|c|c|}
\hline Index type & $\begin{array}{l}\text { S. } \\
\text { no. }\end{array}$ & ID & Name & Definition & Unit \\
\hline \multirow[t]{2}{*}{$\begin{array}{l}\text { Mean temperature } \\
\text { indices }\end{array}$} & 1. & $\mathrm{TNm}$ & Mean TN & $\begin{array}{l}\text { Annual mean daily minimum } \\
\text { temperature }\end{array}$ & ${ }^{\circ} \mathrm{C}$ \\
\hline & 2. & $\mathrm{TXm}$ & Mean TX & $\begin{array}{l}\text { Annual mean daily maximum } \\
\text { temperature }\end{array}$ & ${ }^{\circ} \mathrm{C}$ \\
\hline \multirow{4}{*}{$\begin{array}{l}\text { Absolute-value-based } \\
\text { extreme } \\
\text { temperature indices }\end{array}$} & 3. & $\mathrm{TNn}$ & Min TN & Annual coldest daily TN & ${ }^{\circ} \mathrm{C}$ \\
\hline & 4. & $\mathrm{TNx}$ & $\operatorname{Max} \mathrm{TN}$ & Annual warmest daily TN & ${ }^{\circ} \mathrm{C}$ \\
\hline & 5. & TXn & Min TX & Annual coldest daily TX & ${ }^{\circ} \mathrm{C}$ \\
\hline & 6. & TXx & Max TX & Annual warmest daily TX & ${ }^{\circ} \mathrm{C}$ \\
\hline \multirow[t]{4}{*}{$\begin{array}{l}\text { Percentile-based } \\
\text { extreme } \\
\text { temperature indices }\end{array}$} & 7. & TN10P & $\begin{array}{l}\text { Amount of } \\
\text { cold } \\
\text { nights }\end{array}$ & $\begin{array}{l}\text { Annual percentage of days when } \mathrm{TN}< \\
10^{\text {th }} \text { percentile }\end{array}$ & $\%$ \\
\hline & 8. & TN90P & $\begin{array}{l}\text { Amount of } \\
\text { warm } \\
\text { nights }\end{array}$ & $\begin{array}{l}\text { Annual percentage of days when } \mathrm{TN}> \\
90^{\text {th }} \text { percentile }\end{array}$ & $\%$ \\
\hline & 9. & TX10P & $\begin{array}{l}\text { Amount of } \\
\text { cool days }\end{array}$ & $\begin{array}{l}\text { Annual percentage of days when } \mathrm{TX}< \\
10^{\text {th }} \text { percentile }\end{array}$ & $\%$ \\
\hline & 10. & TX90P & $\begin{array}{l}\text { Amount of } \\
\text { hot days }\end{array}$ & $\begin{array}{l}\text { Annual percentage of days when } \mathrm{TX}> \\
90^{\text {th }} \text { percentile }\end{array}$ & $\%$ \\
\hline \multirow[t]{5}{*}{$\begin{array}{l}\text { Duration-based } \\
\text { extreme } \\
\text { temperature indices }\end{array}$} & 11. & CSDI & $\begin{array}{l}\text { Cold spell } \\
\text { duration } \\
\text { indicator }\end{array}$ & $\begin{array}{l}\text { Annual number of days contributing } \\
\text { to events where six or more } \\
\text { consecutive days experience } \mathrm{TN}< \\
10^{\text {th }} \text { percentile }\end{array}$ & days \\
\hline & 12. & WSDI & $\begin{array}{l}\text { Warm spell } \\
\text { duration } \\
\text { indicator }\end{array}$ & $\begin{array}{l}\text { Annual number of days contributing } \\
\text { to events where six or more } \\
\text { consecutive days experience } \mathrm{TX}> \\
90^{\text {th }} \text { percentile }\end{array}$ & days \\
\hline & 13. & GDDgrow10 & $\begin{array}{l}\text { Growing } \\
\text { degree } \\
\text { days }\end{array}$ & $\begin{array}{l}\text { Annual sum of the daily mean } \\
\text { temperature }(\mathrm{TM})-10\end{array}$ & degree-days \\
\hline & 14. & SU & $\begin{array}{l}\text { Summer } \\
\text { days }\end{array}$ & $\begin{array}{l}\text { Annual number of days when TX> } \\
25^{\circ} \mathrm{C}\end{array}$ & days \\
\hline & 15. & TR & $\begin{array}{r}\text { Tropical } \\
\text { nights }\end{array}$ & $\begin{array}{l}\text { Annual number of days when } \mathrm{TN}> \\
20^{\circ} \mathrm{C}\end{array}$ & days \\
\hline \multirow[t]{3}{*}{$\begin{array}{l}\text { Magnitude-based } \\
\text { precipitation } \\
\text { indices }\end{array}$} & 16. & PRCPTOT & $\begin{array}{l}\text { Total } \\
\text { precipita- } \\
\text { tion }\end{array}$ & Sum of daily precipitation $\geq 1.0 \mathrm{~mm}$ & $\mathrm{~mm}$ \\
\hline & 17. & WDAYS & $\begin{array}{l}\text { Number of } \\
\text { wet days }\end{array}$ & $\begin{array}{l}\text { Number of days when precipitation is } \\
\quad \geq 1.0 \mathrm{~mm}\end{array}$ & days \\
\hline & 18. & SDII & $\begin{array}{l}\text { Simple daily } \\
\text { intensity } \\
\text { index }\end{array}$ & PRCPTOT divided by the WDAYS & $\mathrm{mm} /$ day \\
\hline \multirow{2}{*}{$\begin{array}{l}\text { Absolute-value-based } \\
\text { extreme } \\
\text { precipitation } \\
\text { indices }\end{array}$} & 19. & RX1day & $\begin{array}{l}\text { Max 1-day } \\
\text { precipita- } \\
\text { tion }\end{array}$ & $\begin{array}{l}\text { Maximum annual 1-day precipitation } \\
\text { total }\end{array}$ & $\mathrm{mm}$ \\
\hline & 20. & RX5day & $\begin{array}{l}\text { Max 5-day } \\
\text { precipita- } \\
\text { tion }\end{array}$ & $\begin{array}{l}\text { Maximum annual 5-day precipitation } \\
\text { total }\end{array}$ & $\mathrm{mm}$ \\
\hline \multirow{3}{*}{$\begin{array}{l}\text { Threshold-based } \\
\text { extreme } \\
\text { precipitation } \\
\text { indices }\end{array}$} & 21. & $\mathrm{R} 10 \mathrm{~mm}$ & $\begin{array}{l}\text { Number of } \\
\text { heavy rain } \\
\text { days }\end{array}$ & $\begin{array}{l}\text { Annual number of days when } \\
\text { precipitation is } \geq 10 \mathrm{~mm}\end{array}$ & days \\
\hline & 22. & $\mathrm{R} 30 \mathrm{~mm}$ & $\begin{array}{l}\text { Number of } \\
\text { very } \\
\text { heavy rain } \\
\text { days }\end{array}$ & $\begin{array}{l}\text { Annual number of days when } \\
\text { precipitation is } \geq 30 \mathrm{~mm}\end{array}$ & days \\
\hline & 23. & R95pTOT & & 100*R95p/PRCPTOT & $\%$ \\
\hline
\end{tabular}


Table 1 (continued)

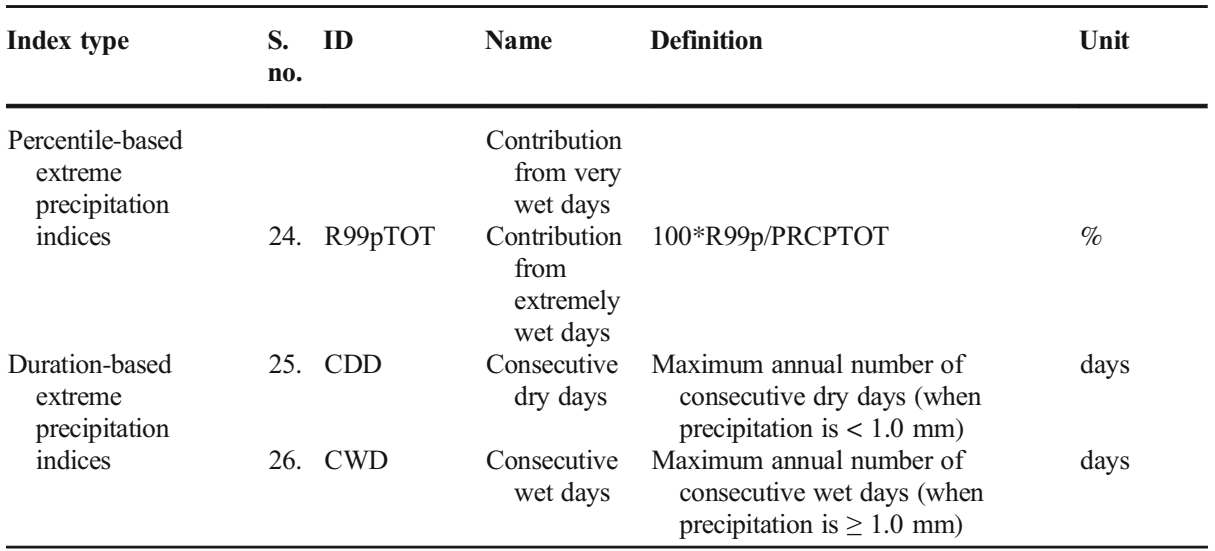

\section{Results and discussion}

\subsection{Projected changes in temperature}

\subsubsection{Mean temperature indices}

Our projections show an increase in the annual mean daily minimum and maximum temperatures (mean TN and TX, respectively) in Karnali; these increases are more pronounced in the highlands and during winter (Fig. 4). In the near future, the annual mean TN and TX are both projected to increase on average by $0.03{ }^{\circ} \mathrm{C} /$ year in RCP 4.5 and by $0.04{ }^{\circ} \mathrm{C} /$ year in RCP8.5. This increasing trend slows in the mid future and is not significant in the far future in RCP4.5

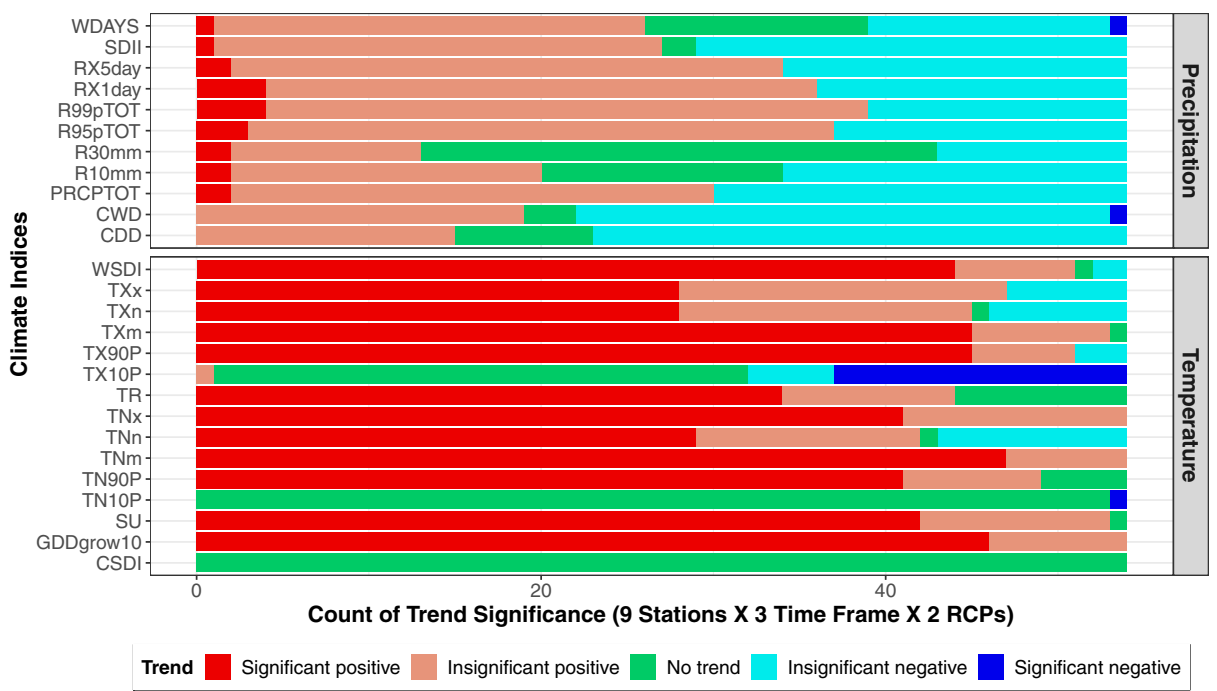

Fig. 3 Future trends of the selected climate indices defined in Table 1. The horizontal axis represents the count of the index trend significance cases out of 54 cases from the nine stations, three future timeframes, and two RCPs 


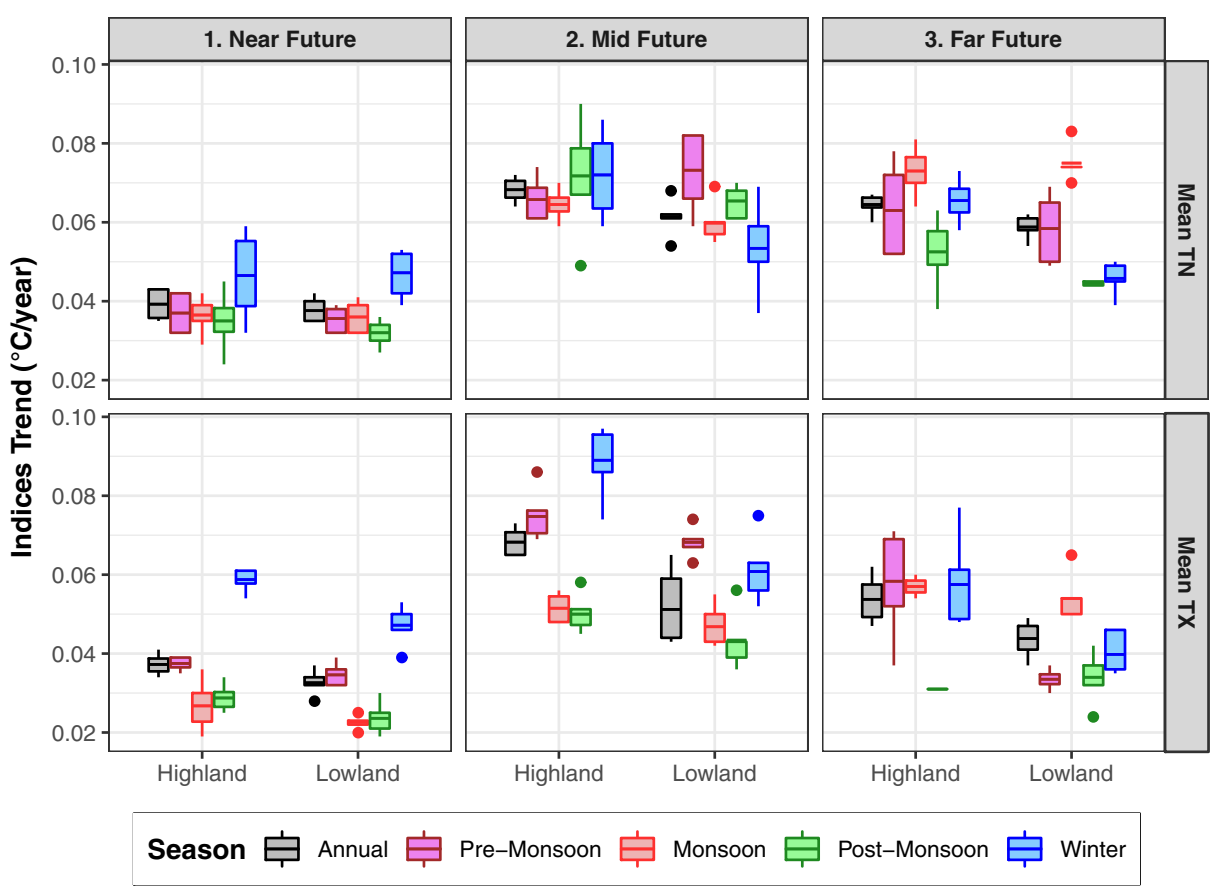

Fig. 4 Projected annual and seasonal mean TN and mean TX trends for Karnali by future timeframe and geographical region in the RCP8.5 scenario. The middle dark lines represent the mean; the boxes represent the interquartile range; the whiskers represent the minimum and maximum values; and the dots represent outliers

(Fig. S2). Conversely, in RCP8.5, the trends for mean TN and TX are $0.06{ }^{\circ} \mathrm{C} /$ year and $0.05^{\circ} \mathrm{C} /$ year, respectively, in the lowlands in the mid future. Both indices increase at a rate of $0.07^{\circ} \mathrm{C} /$ year in the highlands. The winter shows the highest warming rate from the near future with the mean TX increasing as fast as $0.1{ }^{\circ} \mathrm{C} /$ year in the highlands in the mid future. The warming rate is highest during the pre-monsoon in the lowlands. The annual mean TN and TX are projected to continue to increase by $0.06{ }^{\circ} \mathrm{C} /$ year and $0.04{ }^{\circ} \mathrm{C} /$ year, respectively, in the lowlands in the far future. In the highlands, the trends of the mean TN and TX are $0.06{ }^{\circ} \mathrm{C} /$ year and $0.05^{\circ} \mathrm{C} /$ year, respectively. The monsoon shows the highest warming rate in the far future. The higher rate of the mean TN than the mean TX indicates that the nighttime temperature will increase faster than the daytime temperature and that the diurnal temperature range will narrow in the future.

In RCP8.5, by the end of the century, the annual mean $\mathrm{TN}$ and $\mathrm{TX}$ are projected to be 4 $5{ }^{\circ} \mathrm{C}$ and $3.5-4.5{ }^{\circ} \mathrm{C}$ warmer, respectively, in the lowlands and $4.5-6.0{ }^{\circ} \mathrm{C}$ and $4.5-5.0{ }^{\circ} \mathrm{C}$ warmer, respectively, in the highlands than the historical average (Fig. 5). However, these values could exceed $6{ }^{\circ} \mathrm{C}$ during the winter and pre-monsoon in the highlands. In RCP4.5, the annual mean TN and TX will be approximately $1.5-2.5^{\circ} \mathrm{C}$ and $1.0-2.5^{\circ} \mathrm{C}$ warmer, respectively, in the lowlands and $2.0-2.5^{\circ} \mathrm{C}$ and $2.5-3.0^{\circ} \mathrm{C}$ warmer, respectively, in the highlands.

\subsubsection{Absolute-value-based extreme temperature indices}

The annual coldest and warmest daily minimum temperature (min and max $\mathrm{TN}$ ) and maximum temperature (min and max TX) show higher warming than their respective means (mean TN 

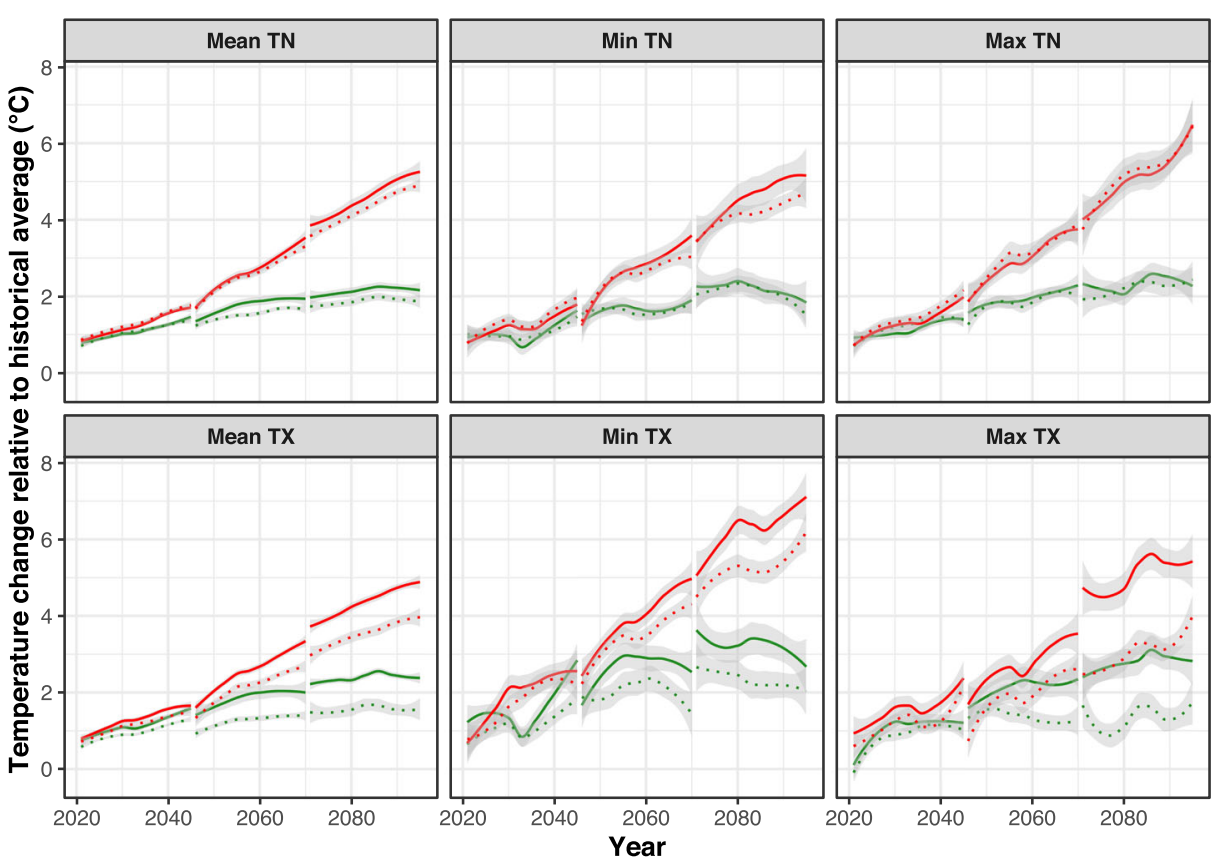

Region - Highland $\cdots$ Lowland $\quad$ Scenario - RCP4.5 - RCP8.5

Fig. 5 Projected mean and extreme temperature index anomalies (base period 1981-2005) for Karnali by future timeframe, scenario, and geographical region. The dark lines represent the locally smooth values, and the gray bands represent the $95 \%$ confidence intervals

and mean TX) discussed in Section 3.1.1. Relative to the historical average, the min and max $\mathrm{TN}$ will be $1.5^{\circ} \mathrm{C}$ and $2.5^{\circ} \mathrm{C}$ higher, respectively, in RCP 4.5 but $4.5^{\circ} \mathrm{C}$ and $6.5^{\circ} \mathrm{C}$ higher, respectively, in RCP8.5 in both the lowlands and the highlands (Fig. 5). The min and max TX will be $1.5^{\circ} \mathrm{C}$ and $2.5^{\circ} \mathrm{C}$ higher, respectively, in the lowlands and $2{ }^{\circ} \mathrm{C}$ and $3{ }^{\circ} \mathrm{C}$ higher, respectively, in the highlands in RCP4.5. In RCP8.5, the min and $\max \mathrm{TX}$ will be $6{ }^{\circ} \mathrm{C}$ and $4.5^{\circ} \mathrm{C}$ higher, respectively, in the lowlands and $6.5^{\circ} \mathrm{C}$ and $6{ }^{\circ} \mathrm{C}$ higher, respectively, in the highlands. The trend of the absolute-value-based extreme temperature indices for Karnali is presented in Fig. S3 in ESM.

\subsubsection{Percentile-based extreme temperature indices}

The amount of hot days (TX90P) and warm nights (TN90P) steeply increases in the range of 1.3-1.9 percentage points/year in the near future in both RCPs (Fig. 6 and Fig. S4). This leads to nearly $100 \%$ and $80-90 \%$ of the days in the year being warmer than the historical hot days and warm-night threshold by the end of the mid future in RCP8.4 and RCP4.5, respectively. Consequently, the amount of cool days (TX10P) and cold nights (TN10P) is already very low in the near future and declines showing no statistically significant trend (Fig. 3). Nearly no days will be below the historical cool days and cold-night threshold in all future scenarios. Such projections, therefore, suggest an alarming increase in extreme temperatures both during the daytime and at night compared to the historical thresholds. A new normal will be necessary to classify extreme temperature thresholds in future contexts. 

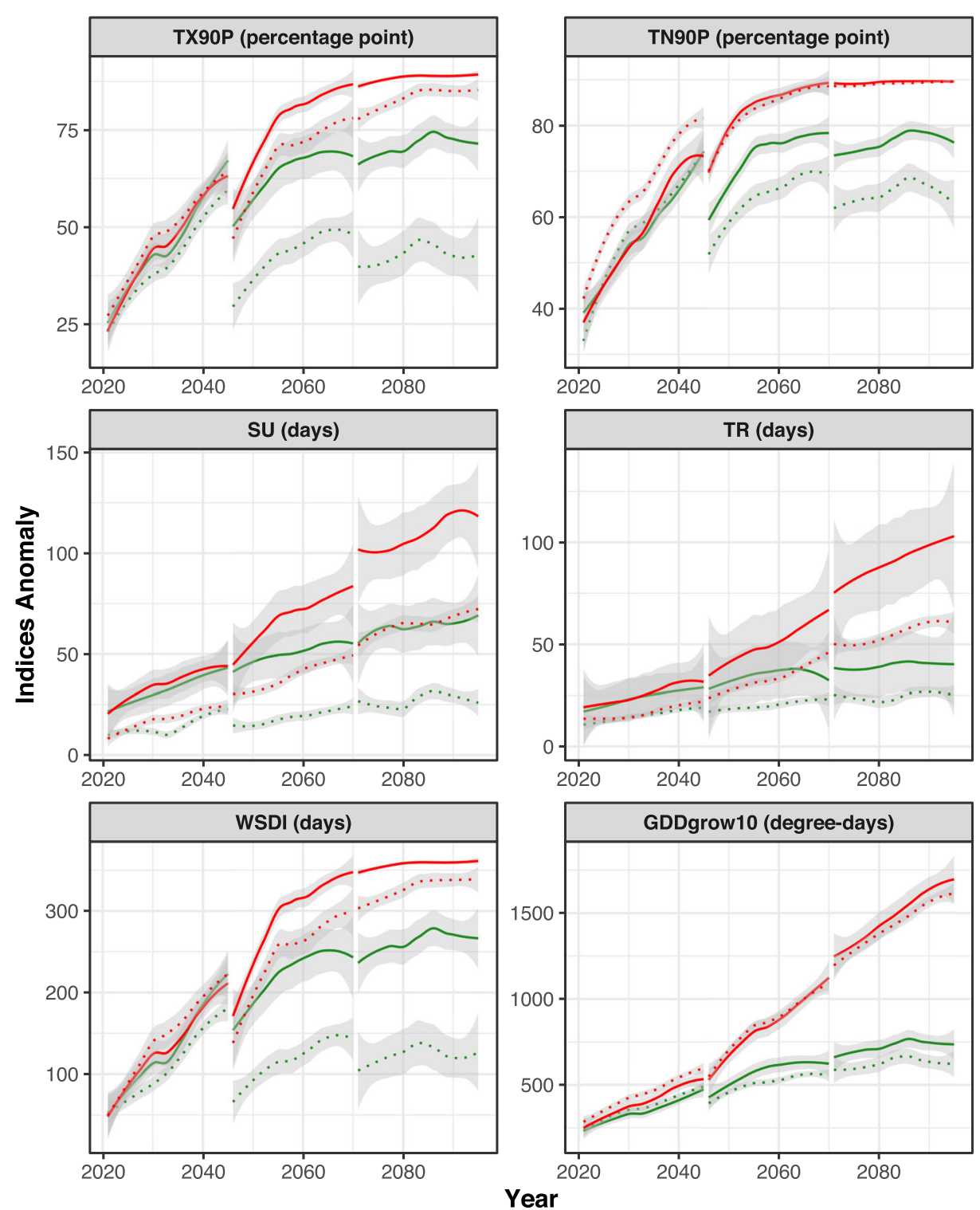

\section{Region - Highland $\cdots$ Lowland Scenario - RCP4.5 - RCP8.5}

Fig. 6 Projected percentile- and duration-based extreme temperature index anomalies for Karnali by future timeframe, geographical region, and emission scenario (different $y$-axis scales are used for each index). Base period, lines, and shading are as in Fig. 5

\subsubsection{Duration-based extreme temperature indices}

Both the number of summer days (SU) and the number of tropical nights (TR) are increasing, similar to the trends of the amount of hot days and warm nights in Section 3.1.3 (Fig. 6). 
However, higher rates are seen for the highlands. For example, SU will increase by $0.5-$ 1.4 days/year in the highlands but by $0.4-0.9$ days/year in the lowlands in the near future for both RCPs (Fig. S4). The rate will slow in RCP4.5 but will increase to 1.2-2.3 days/year in the highlands and 0.7-1.2 days/year in the lowlands in RCP8.5. In the far future, there is no significant trend for RCP4.5; however, SU will increase by $0.7-1.3$ days/year in the highlands, while nearly all 365 days of the year will be summer days in the lowlands. TR shows a similar increasing trend to SU.

The warm spell duration indicator (WSDI) is increasing fastest in the near future at a rate of 5-8 days/year (Fig. 6 and Fig. S4) in both RCPs and both regions. In RCP4.5, the increasing rate slows to 2-5 days/year in the mid future, while the trend is not significant in the far future. In RCP8.5, the increasing rate is 5-7 days/year in the mid future resulting in nearly 365 days of the year being classified as a warm spell in both the highlands and the lowlands in the far future. Subsequently, the cold spell duration indicator (CSDI) has zero values in all future scenarios and shows no trend (Fig. 3).

The growing degree days (GDDgrow10) is a measure of the heat accumulation used to predict plant developmental rates. This index will increase at a rate of 7-10 degree-days/year in RCP4.5 and 9-14 degree-days/year in RCP8.5 in the near future in both regions (Fig. S4). This increasing rate will slow in the mid future, and no significant trend is observed in the far future in RCP4.5. In RCP8.5, GDDgrow10 is projected to increase by 18-25 degree-days/year in the mid future and 17-22 degree-days/year in the far future, with a slightly higher rate in the highlands. By the end of the century, GDDgrow10 will be higher by 1500-2000 degree-days in RCP8.5 and 500-1000 degree-days in RCP4.5 compared to the historical average (Fig. 6).

\subsection{Projected changes in precipitation}

\subsubsection{Magnitude-based precipitation indices}

Unlike temperature, the precipitation indices do not show statistically significant future trends in most cases (Fig. 3). The spatial differences and the differences between the future emission scenarios in precipitation are also not as stark as those seen for temperature. This suggests a higher uncertainty in precipitation trends than in temperature trends. However, the change in annual total precipitation (PRCPTOT) from the historical average is positive in most scenarios (Fig. 7). Therefore, Karnali is projected to receive more annual rainfall than the historical average in all future scenarios. Even though the PRCPTOT trends are not significant, they are mostly positive in the near and far future and negative in the mid future. Similar to the annual total, the changes in the pre-monsoon, monsoon, and post-monsoon precipitation are mostly positive. The largest percentage change from the historical average is projected for the post-monsoon precipitation. However, the percentage change in the winter precipitation, particularly in RCP8.5, is mostly negative. This indicates the occurrence of drier winters in the future.

The simple daily intensity index (SDII) is also mostly positive in the future (Fig. 8). However, the projected annual number of wet days (WDAYS) shows a relatively unchanged pattern in the future. Therefore, the future annual precipitation change is projected to be dominated by higher intensity precipitation than in the past. 


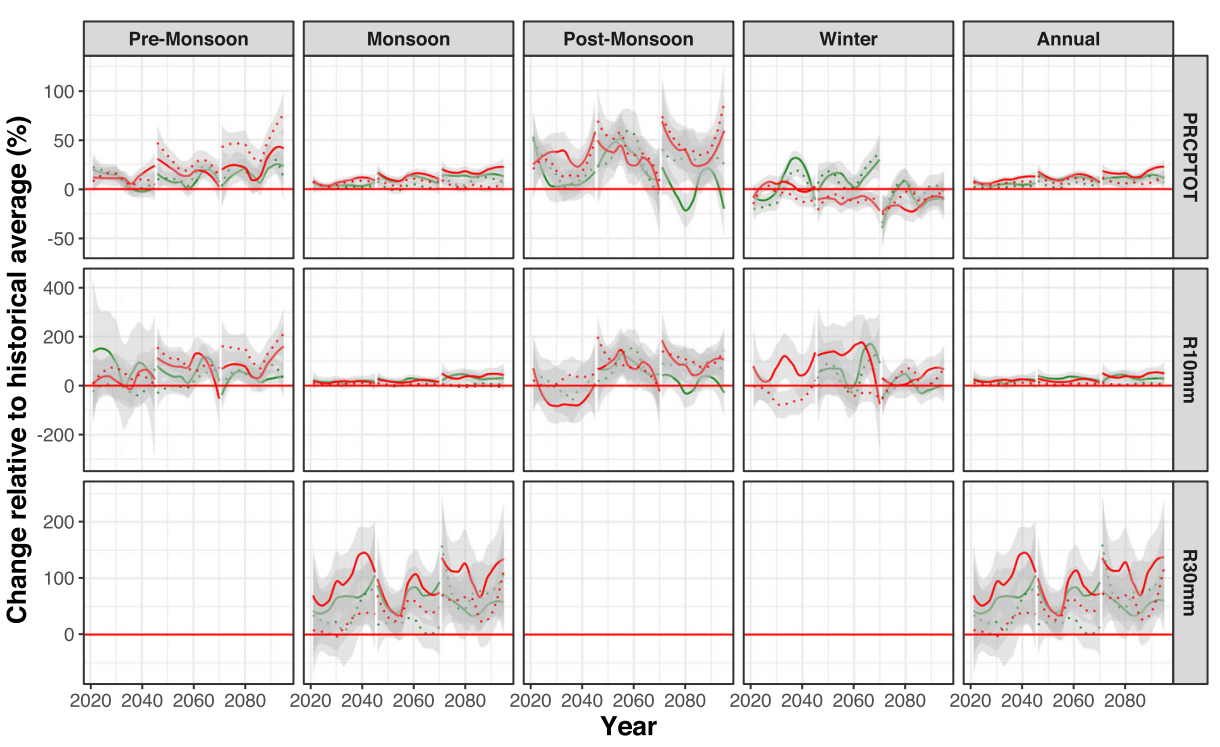

Region - Highland $\cdots$ Lowland Scenario - RCP4.5 - RCP8.5

Fig. 7 Projected percentage change in annual and seasonal total precipitation (PRCPTOT) and number of heavy and very heavy rain days (R10mm and $\mathrm{R} 30 \mathrm{~mm}$ ) for Karnali by future timeframe, geographical region, and emission scenario. Base period, lines, and shading are as in Fig. 5

\subsubsection{Absolute-value-based extreme precipitation indices}

Corroborating the increasing SDII values, the changes in the maximum annual 1- and 5-day precipitation totals (RX1day and RX5day, respectively) are also positive for the future scenarios (Fig. 8). The index trends are also positive, although not significant, in both regions for a majority of the scenarios and negative in some, especially in the far future (Fig. 3). Similarly, the RX1day shows a higher change than the RX5day. The intensities of 1- and 5day extreme precipitation events could be up to $60 \%$ and $40 \%$ higher, respectively, than the historical average in the highlands in the far future.

\subsubsection{Threshold-based extreme precipitation indices}

The numbers of heavy and very heavy rain days (R10mm and R30mm, respectively) show a strong positive change in the future (Fig. 7). The annual R10mm could double in some regions, while the $\mathrm{R} 30 \mathrm{~mm}$ could increase two- to three-fold by the far future. R30mm are rarer events but show a much higher increase in percentage relative to the historical average than $\mathrm{R} 10 \mathrm{~mm}$. The trend values of both indices in most scenarios are not statistically significant. Karnali is projected to experience more heavy rain days in all seasons and more very heavy rain days in the monsoon in the future. Even during the pre- and post-monsoon, Karnali may experience some very heavy rain days in the mid and far future, which was not normal in the past (not shown in Fig. 7 due to extremely high percentage change). 
Fig. 8 Projected percentage change in the extreme precipitation indices from the historical average for Karnali by future timeframe, geographical region, and emission scenario. Base period, lines, and shading are as in Fig. 5

\subsubsection{Percentile-based extreme precipitation indices}

The percentage changes in the contributions from very wet and extremely wet days (R95pTOT and R99pTOT, respectively) are mostly positive in future scenarios (Fig. 8). This is due to the increase in the rainfall intensities, as shown by RX1day and RX5day, and the frequency, as shown by $\mathrm{R} 10 \mathrm{~mm}$ and $\mathrm{R} 30 \mathrm{~mm}$, of extreme precipitation days. The index trends are mostly positive in the near and mid future and both positive and negative in the far future (Fig. 3). The contribution from very wet days could double, and the contribution from extremely wet days could triple compared to the historical average by the far future.

\subsubsection{Duration-based extreme precipitation indices}

Similar to the annual WDAYS, the percentage changes in consecutive dry and wet days (CDD and CWD, respectively) are also equally distributed in negative and positive sides in the near and mid future (Fig. 8). However, the CDD changes are positively skewed, and the CWD changes are negatively skewed, indicating a potential increase in CDD in the far future. The inter-annual and spatial variability of CDD and CWD might also increase in the future.

\subsection{Projection results with respect to historical trends and other future projections}

Our projection results are largely in agreement with the observed historical trends in the region and with other comparable projections. The projected warming in the highlands and lowlands in Karnali by the end of the century is slightly higher than the GCM-based projected national average for the respective regions and scenarios by MoFE (2019) but similar to the projections made for Karnali by Dahal et al. (2020). MoFE (2019) projected average warming of $3.69{ }^{\circ} \mathrm{C}$ and $3.44{ }^{\circ} \mathrm{C}$ in middle mountain and lowlands respectively in the RCP8.5 scenario by $2071-$ 2100. Nevertheless, MoFE (2019) also projected that western Nepal would warm faster than eastern Nepal and that the pre-monsoon and winter would warm the most. The projected higher warming trends in the highlands are consistent with the elevation-dependent warming (EDW) trends observed across Nepal (Khatiwada et al. 2016; DHM 2017; Thakuri et al. 2019; Karki et al. 2019; Dahal et al. 2020). Such EDW in southern Himalaya could be attributed to the weakening monsoon and the reduced cloud cover in the region (Yang et al. 2018; Thakuri et al. 2019; Karki et al. 2019). The faster increase in the mean TN than the mean TX, however, is opposite to the historical warming pattern in Nepal. The weakening winter monsoon in western Nepal could be a cause for higher winter warming leading to a faster increase in mean TN (Wang et al. 2013; Karki et al. 2017; Yang et al. 2018). The projected extreme temperature index trends are largely consistent with the projected increase in warm extremes and decrease in cold extremes across Nepal (Rajbhandari et al. 2017; MoFE 2019; Singh et al. 2021). For example, MoFE (2019) projected that the hot days in Nepal will increase by $87 \%$ in RCP4.5 and $125 \%$ in RCP 8.5 by the end of the century. Similarly, the cold nights will decrease by $53 \%$ and $74 \%$ in the respective scenarios. Nevertheless, it is hard to make one-to-one comparison of these indices due to the underlying differences such as baseline period, location, and climate 


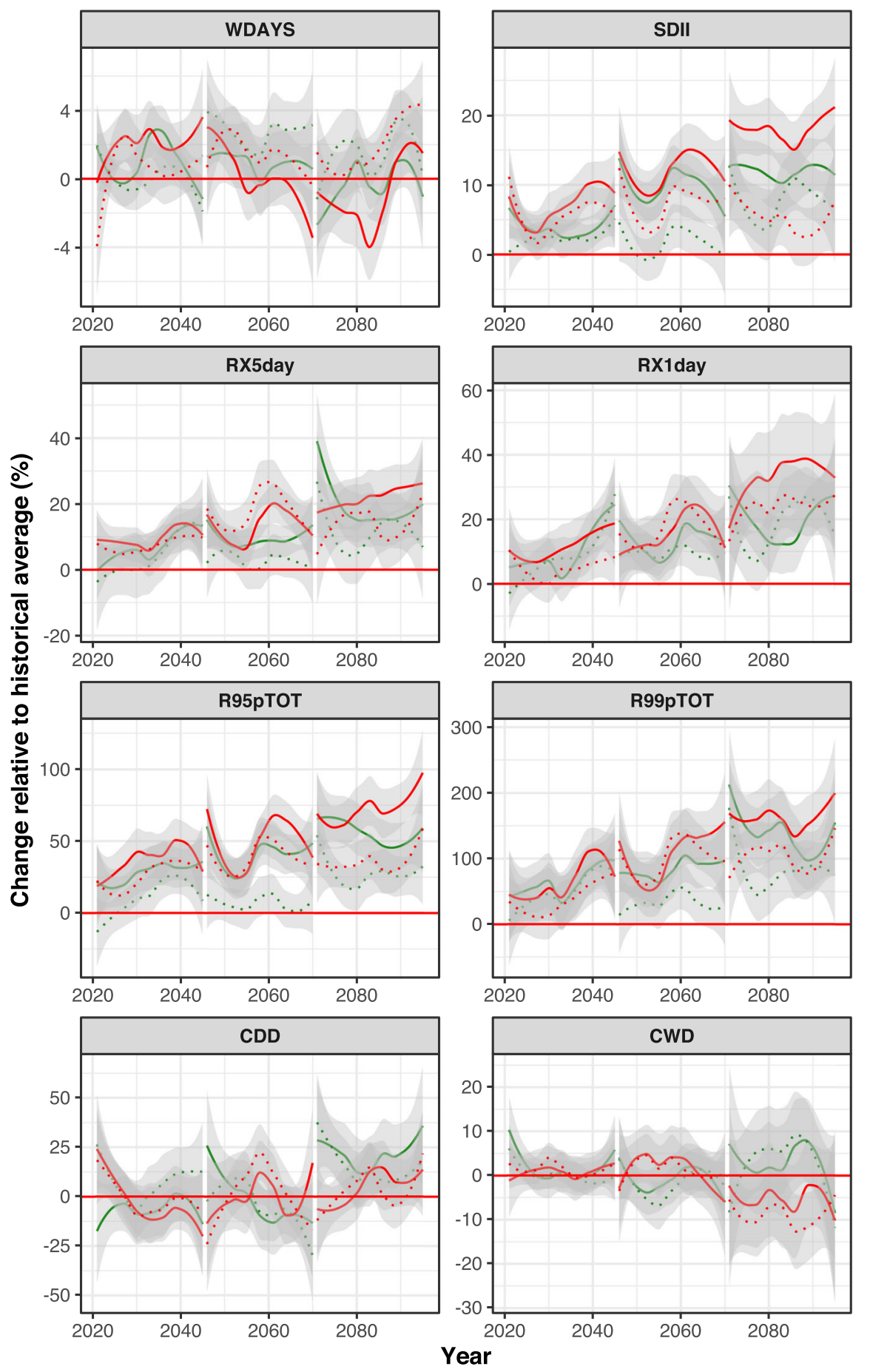

Region - Highland $\cdots$ Lowland Scenario - RCP4.5 - RCP8.5 
models used. A similar increasing trend of hot extremes and decreasing trend of cold extremes was observed in the historical period (DHM 2017; Bohlinger and Sorteberg 2018; Karki et al. 2019; Poudel et al. 2020).

The projected increase in the annual total precipitation in Karnali agrees with the historically observed increasing annual precipitation trend in western Nepal (Khatiwada et al. 2016; Karki et al. 2017; Sharma et al. 2020), even though some studies (Khatiwada et al. 2016; Pokharel et al. 2019; Dahal et al. 2020) also reported a decreasing trend, mainly in the lowlands. In the future, Dahal et al. (2020), MoFE (2019), and Pokharel et al. (2019) all project an increase in the annual total precipitation but a decrease in winter precipitation similar to the projection in our study. A decreasing trend in the winter precipitation in western Nepal has already been observed in the historical period (Khatiwada et al. 2016; Karki et al. 2017). Wang et al. (2013) argue that the decreasing winter precipitation in western Nepal is linked with the warming sea surface temperature in the Indian Ocean, alteration of Arctic Oscillation, and rise in anthropogenic aerosols. High-intensity extreme precipitation events are more common in Karnali compared to other parts of Nepal (Karki et al. 2017; Bohlinger and Sorteberg 2018; Talchabhadel et al. 2018; Pokharel et al. 2019). Furthermore, these studies reported an increasing trend in extreme precipitation in the past. The projected increase in the frequency and intensity of the extreme precipitation indices is in line with other projections for Nepal (MoFE 2019; Rajbhandari et al. 2017; Singh et al. 2021). MoFE (2019) projected that there will be around $20 \%$ more very wet days but $60 \%$ more extreme precipitation days in Nepal by the end of the century in RCP8.5.

\subsection{Sectoral implications}

\subsubsection{Water resources and energy}

Projection results indicate that the Karnali region will experience a change in the precipitation patterns with wet-get-wetter and dry-get-drier. The increase in the RX1day and RX5day, R10mm and R30mm, and R95pTOT and R99pTOT will increase the peak flow. The increased peak flow may cause damage to hydropower and irrigation infrastructures and siltation. On the other hand, the decrease in the occurrence of both scattered and consecutive low-intensity rainy days will reduce the percolation of water into the subsurface affecting groundwater recharge and subsequent baseflow contribution to streams, natural springs, and aquifer storages. Such decline in base flow could affect water available for electricity generation or agriculture. The projected decrease in winter precipitation, when the water availability and river flow are lowest (Dahal et al. 2020; Khatiwada et al. 2016), followed by hot and dry premonsoon can increase the water stress in the region in the future. This could exacerbate migration and settlement displacement in the highlands, as observed in other parts of the country (Joshi and Dongol 2018).

\subsubsection{Climate-induced disasters}

A projected increase in both the intensity (shown by RX1day and RX5day) and the frequency (shown by $\mathrm{R} 10 \mathrm{~mm}$ and $\mathrm{R} 30 \mathrm{~mm}$ ) of extreme precipitation events, mainly during the already very wet monsoon, could increase the risk of landslides and erosion in the highlands. The increase in the peak flow caused by the increase in extreme rain could exacerbate flash floods and cause the inundation of fields and settlements in the 
lowlands. Because the maximum 1- and 5-day precipitation is projected to increase by $40-60 \%$, even a single extreme event could be devastating. Moreover, the increasing $\mathrm{R} 10 \mathrm{~mm}$ in all future timeframes and the occurrence of $\mathrm{R} 30 \mathrm{~mm}$ in the far future, even during the pre- and post-monsoon, indicate the possibility of these disasters occurring even during the dry season. An increase in the probability of floods and landslides in the historically dry season is alarming because such events are more likely to catch people off-guard.

The projected higher increase in temperature in the highlands could accelerate Himalayan glacier retreat and increase the size and number of glacial lakes, increasing the risk of glacial lake outburst floods. The highest warming of the mean and extreme temperatures in the lowlands during the hot pre-monsoon and monsoon and extended warm spells could increase the risk of heatwaves in the future. This risk is even higher in the growing urban areas because of the urban heat island effect.

\subsubsection{Agriculture and food security}

The spatial differences in the projected climate extremes in Karnali indicate varying implications for agriculture in the highlands and lowlands in the short and long term. The decline in cold nights and increase in mean temperatures, warm spells, and growing degree days suggest that more areas in the highlands could become favorable for agriculture. A potential increase in the annual precipitation also favors this expansion. According to some studies, current subsistence farming in Karnali could expand to grow crops such as rice, maize, bananas, and vegetables at higher altitudes, provided other conditions, such as water availability and soil fertility, are favorable (Bhatt et al. 2014; Ranjitkar et al. 2016). Nevertheless, the increasing temperature has already shown negative impacts on major cereal crop (wheat, rice, and maize) production in Karnali, Dudh Koshi, and other parts of the country (Bocchiola et al. 2019; Khatiwada and Pandey 2019), warning against a focus on the potential expansion of cultivable areas with increasing temperatures in the highlands.

The compounded effect of the changes in the temperature and precipitation patterns will directly influence crop physiological processes, crop seasons, phenology, and crop cultivation suitability, while increasing the incidence of disease, pests, and other disasters affecting crop production (Bocchiola et al. 2019; Aryal et al. 2020). Therefore, the negative consequences of the projected climate on the crop yield will most likely surpass the positive impacts in the long term, worsening food insecurity in the region. Bhatt et al. (2014) pointed out that many crops are already under temperature stress in the lowlands, with impacts likely to worsen because the mean and extreme maximum temperatures are projected to increase by as much as $6{ }^{\circ} \mathrm{C}$ by the end of the century in RCP8.5.

Any change in the precipitation patterns will challenge the existing agricultural practices in Karnali that largely remain rain-fed and will increase the uncertainties in farmer decisionmaking. The projected decrease in the critical winter precipitation and increase in temperature will affect winter crops such as wheat, potatoes, oilseeds, and vegetables. Similarly, the temperature increases could also increase evapotranspiration. As frequent and severe droughts observed over the last decade in Karnali have already shown, such dry conditions and decreased soil moisture will lead to a decrease in the crop yield and soil degradation over time (Wang et al. 2013; Khatiwada and Pandey 2019). The actual level of the impact on agriculture also depends on the extent to which farmers adapt their agricultural practices to the changing climate. 


\subsubsection{Forests and biodiversity}

The forests and biodiversity along the south-north transect in Karnali will respond differently to the projected changes. The increasing average temperature will shift the climate boundaries northward in Nepal's Himalaya ultimately affecting the current biome and species distribution (Zomer et al. 2014; Talchabhadel and Karki 2019). Grasslands and shrublands in the highlands in Karnali include several endemic species and high-value medicinal plants, such as Yarsagumba (Ophiocordyceps sinensis). However, such sensitive alpine ecosystems may experience hot days and nights during $80-90 \%$ of the year by the mid future, even in the RCP4.5 scenario. Winter could be more than $6{ }^{\circ} \mathrm{C}$ warmer by the end of the century in RCP8.5. The characteristic cold winter climate of the highlands could vanish in the long term because the mean and extreme temperature warming rate is highest in the highlands. Such warming will enable a future advance of tree lines, and such a shift in the tree line into treeless ecosystems could have major consequences, such as decreases in alpine diversity, carbon storage, and ecosystem services (Schickhoff et al. 2016; Bhattacharjee et al. 2017).

The projected higher temperature will favor the expansion of climatically suitable regions for invasive alien plants in the southern tropical and temperate forest and agricultural lands; this has already been observed in the region (Bhatta et al. 2020; Shrestha and Shrestha 2019). The expanded summer and warm spells may cause changes in the vegetation phenology and an early onset of the growing season, particularly in the ecoregions of higher elevations in Karnali, as indicated in the literature (Xu et al. 2009; Shrestha et al. 2012). A prolonged dry period due to the projected warmer and drier winter followed by a hot and dry premonsoon could aggravate the incidence of forest fires, further endangering terrestrial biodiversity. Expanded warm spells and reduced winter precipitation could also negatively impact the water availability and ecosystem in important wetlands such as Rara and Phoksundo in the highlands and Ghodaghodi in the lowlands. Changes in the river flows in response to changing precipitation patterns will also affect aquatic biodiversity (Poff and Zimmerman 2010).

\subsubsection{Tourism and natural and cultural heritage}

National parks and wildlife reserves, high-altitude wetlands, rivers, mountains, and indigenous culture are among the major tourist attractions in Karnali. The degradation of the natural heritage due to the projected changes may negatively affect the tourism industry in the future. More summer days in the highlands could have a positive impact on tourism in the short term (K.C. 2017). However, the projected increase in climate extremes, such as the mean and extreme daytime temperature, hot days, and number of heavy and very heavy rain days, will reduce favorable weather conditions for major tourist activities such as trekking, mountaineering, river rafting, and jungle safaris. Such tourist activities are highly climate-sensitive, and unfavorable climatic conditions may cause locational and seasonal shifts in tourist flows (K.C. 2017). The highest precipitation increase and increased chances of heavy and very heavy rain days during the pre- and post-monsoon, which are also the peak tourist seasons in Nepal (K.C. et al. 2020), could severely affect tourism by hindering mobility (both land and air) and increasing the probability of climate disasters. Mountaineering is very sensitive to snow cover and favorable climatic windows. Projected warming-induced snow cover loss and an uncertain climate could negatively affect mountain tourism. Temperature increases could also increase 
costs for tourism entrepreneurs because they will need to invest more in cooling systems in lowland areas.

\subsubsection{Public health}

The projected increase in the mean temperature will increase the risk of vector-borne diseases (such as dengue, malaria, and Japanese encephalitis), water-borne diseases (such as diarrhea and hepatitis), and other health risks in Karnali. Every unit increase in the mean TN at a lag of 2 months increases the incident rate ratio of dengue cases by more than $1 \%$ in southern Nepal (Tuladhar et al. 2019). Similarly, a $1{ }^{\circ} \mathrm{C}$ increase in the mean $\mathrm{TN}$ increases the malaria incidence by $27 \%$ (Dhimal et al. 2014). Water scarcity during dry and hot summers may lead to poor hygienic practices and an increase in the risk of disease prevalence (Bhandari et al. 2020; Dhimal et al. 2015; Shrestha et al. 2016; Tuladhar et al. 2019). Altogether, this indicates a higher risk of vector-borne diseases over a larger area in Karnali and an intensified risk of epidemics in the future. Water-borne diseases could also increase in the future; Bhandari et al. (2020) found that a $1{ }^{\circ} \mathrm{C}$ increase in the mean TX and a $10-\mathrm{mm}$ increase in the monthly precipitation increase the monthly count of diarrhea cases in Kathmandu by $8.1 \%$ and $0.9 \%$, respectively. A projected increase in hot extremes, hot days, and warm spells in the already hot tropical lowlands could cause heat stress, leading to an increase in morbidity and mortality, as observed by Shrestha et al. (2016).

\section{Limitations}

Future climate projections and bias corrections come with inherent uncertainties. Therefore, the projected results and sectoral implications should be interpreted with caution. To better capture the highly heterogeneous terrain in western Nepal, we use bias-corrected RCM-based projections over GCM-based projections, as RCMs are better able to resolve meso-scale climatic processes in regions with highly variable topography (Flato et al. 2013). However, bias-corrected RCM projections are provided by Dhaubanjar et al. (2020) only for a limited number of stations. Many stations were discarded due to short and poor-quality data that results in poor performance in the quantile-mapping method for bias correction. The nine stations used here are skewed toward the southern lowlands increasing the uncertainty in our interpretations for the northern mountainous regions.

In addition, we further consolidated the data across the nine stations into two geographical regions (lowlands and highlands) to interpret the index trends across the study area. Thus, the regional inferences made here by consolidating a limited number of stations are most applicable for areas closest to our study stations. Higher uncertainty should be assumed when applying our index trends and sectoral implication to areas farther away from these stations.

The selection of different indices as relevant to different sectors was a subjective iterative process. In general, sectorial experts were unfamiliar with the ET-SCI indices and struggled with defining their linkage to their sectors. More dialogs are required between climatologists and sector experts to improve upon the first efforts we have made to designate and interpret sector-specific indices for Karnali. Quantifying future impacts to different sectors is difficult because there are limited studies that quantify the relationship between ET-SCI indices and sectoral activities in Nepal. Future research could develop a quantitative projection of impacts to each sector, building on the qualitative analysis we performed here. 


\section{Conclusions}

The projections of the 26 ET-SCI climate indices examined here suggest that both the temperature and precipitation patterns in Karnali will already change significantly from their historical patterns in the near future, irrespective of the emission scenario. If the global emission pathways do not follow stronger emission reductions, the region will encounter a much more extreme climate in the mid and far future. The northern highlands in Karnali are projected to warm faster than the southern lowlands. Because of its highest warming rate and decrease in precipitation, winter in the highlands is expected to be warmer and dryer. The already hot and wet summer in the lowlands will be hotter with more extreme temperatures and scattered extreme precipitation events. The hottest days and nights will be hotter, summer and warm spells will be longer, and cold days will be fewer. The increasing precipitation intensity (SDII), maximum 1- and 5-day precipitation (RX1day and RX5day), and contribution from very wet and extremely wet days (R95pTOT and R99pTOT) suggest an increase in sporadic higher intensity rains and fewer days of low-intensity rains throughout the year. The frequency (R10mm and R30mm) and intensity (RX1day and RX5day) of extreme precipitation events will be much higher in all futures, even in the dry season in the far future. All these projected changes in the temperature and precipitation will have largely negative implications for the six climate-sensitive sectors in Karnali. Therefore, there is an urgent need to plan adaptation measures to reduce risks and strengthen the climate resilience of the key sectors in Karnali.

Supplementary Information The online version contains supplementary material available at https://doi.org/ 10.1007/s10584-021-03216-8.

Acknowledgements The authors are thankful to all the participants of the stakeholder's consultation and expert interview. Special thanks to Vishnu Prasad Pandey and Katrin Blauth for their initial inputs in setting up this research. We are thankful to three anonymous reviewers for their valuable feedback.

Code availability The authors used open-source ClimPACT2 software and custom code, which can be made available upon reasonable request.

Author contribution All authors contributed to the study design. Dipesh Chapagain analyzed the data and wrote the manuscript with inputs from Sanita Dhaubanjar and Luna Bharati.

Funding Open Access funding enabled and organized by Projekt DEAL. The authors acknowledge the financial support from the United States Agency for International Development and the doctoral scholarship program of the Heinrich Böll Foundation.

Data availability The datasets used and generated during this study can be made available upon reasonable request.

\section{Declarations}

Conflict of interest The authors declare no competing interests.

Open Access This article is licensed under a Creative Commons Attribution 4.0 International License, which permits use, sharing, adaptation, distribution and reproduction in any medium or format, as long as you give appropriate credit to the original author(s) and the source, provide a link to the Creative Commons licence, and indicate if changes were made. The images or other third party material in this article are included in the article's 
Creative Commons licence, unless indicated otherwise in a credit line to the material. If material is not included in the article's Creative Commons licence and your intended use is not permitted by statutory regulation or exceeds the permitted use, you will need to obtain permission directly from the copyright holder. To view a copy of this licence, visit http://creativecommons.org/licenses/by/4.0/.

\section{References}

Aksha SK, Juran L, Resler LM (2018) Spatial and temporal analysis of natural hazard mortality in Nepal. Environ Hazards 17:163-179. https://doi.org/10.1080/17477891.2017.1398630

Aryal JP, Sapkota TB, Khurana R et al (2020) Climate change and agriculture in South Asia: adaptation options in smallholder production systems. Environ Dev Sustain 22:5045-5075. https://doi.org/10.1007/s10668019-00414-4

Bhandari D, Bi P, Sherchand JB et al (2020) Assessing the effect of climate factors on childhood diarrhoea burden in Kathmandu, Nepal. Int J Hyg Environ Health 223:199-206. https://doi.org/10.1016/j.ijheh.2019. 09.002

Bharati L, Gurung P, Jayakody P et al (2014) The projected impact of climate change on water availability and development in the Koshi Basin, Nepal. Mt Res Dev 34:118-130. https://doi.org/10.1659/MRDJOURNAL-D-13-00096.1

Bharati L, Bhattarai U, Khadka A et al (2019) From the mountains to the plains: impact of climate change on water resources in the Koshi River Basin. International Water Management Institute, Colombo, Sri Lanka

Bhatt D, Maskey S, Babel MS et al (2014) Climate trends and impacts on crop production in the Koshi River basin of Nepal. Reg Environ Chang 14:1291-1301. https://doi.org/10.1007/s10113-013-0576-6

Bhatta S, Joshi LR, Shrestha BB (2020) Distribution and impact of invasive alien plant species in Bardia National Park, western Nepal. Environ Conserv 47:197-205. https://doi.org/10.1017/S0376892920000223

Bhattacharjee A, Anadón JD, Lohman DJ et al (2017) The impact of climate change on biodiversity in Nepal: current knowledge, lacunae, and opportunities. Climate 5:80

Bocchiola D, Brunetti L, Soncini A et al (2019) Impact of climate change on agricultural productivity and food security in the Himalayas: a case study in Nepal. Agric Syst 171:113-125. https://doi.org/10.1016/j.agsy. 2019.01.008

Bohlinger P, Sorteberg A (2018) A comprehensive view on trends in extreme precipitation in Nepal and their spatial distribution. Int J Climatol 38:1833-1845. https://doi.org/10.1002/joc.5299

CBS (2020) Nepal statistical year book 2019. Central Bureau of Statistics, Kathmandu, Nepal

Chalise S, Naranpanawa A, Bandara JS, Sarker T (2017) A general equilibrium assessment of climate changeinduced loss of agricultural productivity in Nepal. Econ Model 62:43-50. https://doi.org/10.1016/j.econmod. 2017.01.014

Clarke JM, Whetton PH, Hennessy KJ (2011) Providing application-specific climate projections datasets: CSIRO's climate futures framework. In: 19th International Congress on Modelling and Simulation. Perth, Australia, pp. 2683-2687

Dahal P, Shrestha ML, Panthi J, Pradhananga D (2020) Modeling the future impacts of climate change on water availability in the Karnali River Basin of Nepal Himalaya. Environ Res 185:109430. https://doi.org/10.1016/ j.envres.2020.109430

Devkota LP, Gyawali DR (2015) Impacts of climate change on hydrological regime and water resources management of the Koshi River Basin, Nepal. J Hydrol Reg Stud 4:502-515. https://doi.org/10.1016/j. ejrh.2015.06.023

Dhaubanjar S, Pandey VP, Bharati L (2020) Climate futures for Western Nepal based on regional climate models in the CORDEX-SA. Int J Climatol 40:2201-2225. https://doi.org/10.1002/joc.6327

Dhimal M, O’Hara RB, Karki R et al (2014) Spatio-temporal distribution of malaria and its association with climatic factors and vector-control interventions in two high-risk districts of Nepal. Malar J 13:457. https:// doi.org/10.1186/1475-2875-13-457

Dhimal M, Ahrens B, Kuch U (2015) Climate change and spatiotemporal distributions of vector-borne diseases in Nepal-a systematic synthesis of literature. PLoS One 10:e0129869. https://doi.org/10.1371/journal.pone. 0129869

DHM (2017) Observed climate trend analysis in the districts and physiographic regions of Nepal (1971-2014). Kathmandu, Nepal

DNPWC (2020) Department of National Parks and Wildlife Conservation, Government of Nepal. http://www. dnpwc.gov.np/en/. Accessed 25 Nov 2020

Eckstein D, Künzel V, Schäfer L (2021) Global Climate Risk Index 2021. Bonn, Germany 
ETCCDI (2009) Guidelines on analysis of extremes in a changing climate in support of informed decisions for adaptation. Geneva, Switzerland

ET-SCI (2016) Expert Team on Sector-specific Climate Indices (ET-SCI) and ClimPACT2 user guide

Flato G, Marotzke J, Abiodun B, et al (2013) Evaluation of Climate Models. In: Climate Change 2013: The Physical Science Basis. Contribution of Working Group I to the Fifth Assessment Report of the Intergovernmental Panel on Climate Change. Cambridge University Press, Cambridge, pp 741-866

IPCC (2013) Climate Change 2013: The Physical Science Basis. Contribution of Working Group I to the Fifth Assessment Report of the Intergovernmental Panel on Climate Change [Stocker, T.F., D. Qin, G.-K. Plattner, M. Tignor, S.K. Allen, J. Boschung, A. Nauels, Y. Xia,. Cambridge, United Kingdom and New York, NY, USA

IPCC (2021) Summary for policymakers. In: Climate Change 2021: The Physical Science Basis. Contribution of Working Group I to the Sixth Assessment Report of the Intergovernmental Panel on Climate Change [Masson-Delmotte, V., P. Zhai, A. Pirani, S. L. Connors, C. Péan

IWMI (2018) Hydropower and irrigation projects in Western Nepal. Digo Jal Bikas, International Water Management Institute (IWMI)

Jha R (2010) Total run-of-river type hydropower potential of Nepal. Hydro Nepal J Water, Energy Environ 7:813. https://doi.org/10.3126/hn.v7i0.4226

Joshi N, Dongol R (2018) Severity of climate induced drought and its impact on migration: a study of Ramechhap District, Nepal

K.C. A (2017) Climate Change and its Impact on Tourism in Nepal. J Tour Hosp Educ 7:25-43. https://doi.org/ $10.3126 /$ jthe.v7i0.17688

K.C. A, Ghimire S, Dhakal A (2020) Ecotourism and its impact on indigenous people and their local environment: case of Ghalegaun and Golaghat of Nepal. GeoJournal. https://doi.org/10.1007/s10708-02010222-3

Karki R, Hasson S ul, Schickhoff U, et al (2017) Rising Precipitation Extremes across Nepal. Climate 5:4. https:// doi.org/10.3390/cli5010004

Karki R, Hasson S ul, Gerlitz L, et al (2019) Rising mean and extreme near-surface air temperature across Nepal. Int J Climatol 40:2445-2463. https://doi.org/10.1002/joc.6344

Kendall MG (1975) Rank correlation methods. Griffin

Khatiwada KR, Pandey VP (2019) Characterization of hydro-meteorological drought in Nepal Himalaya: a case of Karnali River Basin. Weather Clim Extrem 26:100239. https://doi.org/10.1016/j.wace.2019.100239

Khatiwada KR, Panthi J, Shrestha ML, Nepal S (2016) Hydro-climatic variability in the Karnali River Basin of Nepal Himalaya. Climate 4:17. https://doi.org/10.3390/cli4020017

Knutti R, Abramowitz G, Collins M et al (2010) Good practice guidance paper on assessing and combining multi model climate projections. Bern, Switzerland

Mann HB (1945) Nonparametric tests against trend. Econometrica 13:245. https://doi.org/10.2307/1907187

Matheswaran K, Khadka A, Dhaubanjar S et al (2019) Delineation of spring recharge zones using environmental isotopes to support climate-resilient interventions in two mountainous catchments in Far-Western Nepal. Hydrogeol J:1-17. https://doi.org/10.1007/s10040-019-01973-6

MoFE (2019) Climate change scenarios for Nepal for National Adaptation Plan (NAP). Kathmandu, Nepal

MoPE (2017) Vulnerability and risk assessment framework and indicators for National Adaptation Plan (NAP) formulation process in Nepal. Kathmandu, Nepal

ND-GAIN (2018) Notre Dame-Global Adaptation Index (ND-GAIN). https://gain.nd.edu/our-work/countryindex/rankings/. Accessed 19 Jan 2021

Nepal S (2016) Impacts of climate change on the hydrological regime of the Koshi river basin in the Himalayan region. J Hydro-environment Res 10:76-89. https://doi.org/10.1016/j.jher.2015.12.001

NPC (2018) Nepal's multidimensional poverty index: analysis towards action. Kathmandu, Nepal

Pandey VP, Dhaubanjar S, Bharati L, Thapa BR (2020) Spatio-temporal distribution of water availability in Karnali-Mohana Basin, Western Nepal: climate change impact assessment (Part-B). J Hydrol Reg Stud 29: 100691. https://doi.org/10.1016/j.ejrh.2020.100691

Panthi J, Khatiwada KR, Shrestha ML, Dahal P (2018) Water poverty in the context of climate change: a case study from Karnali river basin in Nepal Himalaya. Int J River Basin Manag 17:243-250. https://doi.org/10. $1080 / 15715124.2018 .1531421$

Poff NL, Zimmerman JKH (2010) Ecological responses to altered flow regimes: a literature review to inform the science and management of environmental flows. Freshw Biol 55:194-205. https://doi.org/10.1111/j.13652427.2009.02272.x

Pokharel B, Wang S-YS, Meyer J et al (2019) The east-west division of changing precipitation in Nepal. Int J Climatol 40:3348-3359. https://doi.org/10.1002/joc.6401

Poudel A, Cuo L, Ding J, Gyawali AR (2020) Spatio-temporal variability of the annual and monthly extreme temperature indices in Nepal. Int J Climatol 40:4956-4977. https://doi.org/10.1002/joc.6499 
Rajbhandari R, Shrestha AB, Nepal S et al (2017) Extreme climate projections over the transboundary Koshi River Basin using a high resolution regional climate model. Adv Clim Chang Res 8:199-211. https://oi. org/10.1016/j.accre.2017.08.006

Ranjitkar S, Sujakhu NM, Merz J et al (2016) Suitability analysis and projected climate change impact on banana and coffee production zones in Nepal. PLoS One 11:e0163916. https://doi.org/10.1371/journal.pone. 0163916

Sanjay J, Ramarao M, Mujumdar M, Krishnan R (2017) Regional climate change scenarios. In: Rajeevan MN, Nayak S (eds) Observed climate variability and change over the Indian region. Springer Singapore, Singapore, pp 285-305

Schickhoff U, Bobrowski M, Böhner J et al (2016) Climate change, glacier response, and vegetation dynamics in the Himalaya. Springer International Publishing, Cham

Sen PK (1968) Estimates of the regression coefficient based on Kendall's tau. J Am Stat Assoc 63:1379-1389

Sharma S, Khadka N, Hamal K, Baniya B (2020) Spatial and temporal analysis of precipitation and its extremities in seven provinces of Nepal (2001-2016). Appl Ecol Environ Sci 8:64-73. https://doi.org/10. 12691/aees-8-2-4

Shrestha UB, Shrestha BB (2019) Climate change amplifies plant invasion hotspots in Nepal. Divers Distrib 25: 1599-1612. https://doi.org/10.1111/ddi.12963

Shrestha UB, Gautam S, Bawa KS (2012) Widespread climate change in the Himalayas and associated changes in local ecosystems. PLoS One 7:e36741. https://doi.org/10.1371/journal.pone.0036741

Shrestha SL, Shrestha IL, Shrestha N (2016) Region-wise effects of climate sensitive variables on some specific disease burdens in Nepal. Open Atmos Sci J 10:63-83. https://doi.org/10.2174/1874282301610010063

Singh R, Pandey VP, Kayastha SP (2021) Hydro-climatic extremes in the Himalayan watersheds: a case of the Marshyangdi Watershed, Nepal. Theor Appl Climatol 143:131-158. https://doi.org/10.1007/s00704-02003401-2

Talchabhadel R, Karki R (2019) Assessing climate boundary shifting under climate change scenarios across Nepal. Environ Monit Assess 191:520. https://doi.org/10.1007/s10661-019-7644-4

Talchabhadel R, Karki R, Thapa BR et al (2018) Spatio-temporal variability of extreme precipitation in Nepal. Int J Climatol 38:4296-4313. https://doi.org/10.1002/joc.5669

Thakur KK, Pant GR, Wang L et al (2012) Seroprevalence of Japanese encephalitis virus and risk factors associated with seropositivity in pigs in four mountain districts in Nepal. Zoonoses Public Health 59:393400. https://doi.org/10.1111/j.1863-2378.2012.01456.x

Thakuri S, Dahal S, Shrestha D et al (2019) Elevation-dependent warming of maximum air temperature in Nepal during 1976-2015. Atmos Res 228:261-269. https://doi.org/10.1016/j.atmosres.2019.06.006

Tuladhar R, Singh A, Varma A, Choudhary DK (2019) Climatic factors influencing dengue incidence in an epidemic area of Nepal. BMC Res Notes 12:131. https://doi.org/10.1186/s13104-019-4185-4

UN-WFP (2014) Climate risk and food security in Nepal: analysis of climate impacts on food security and livelihoods. Kathmandu

Wang S-Y, Yoon J-H, Gillies RR, Cho C (2013) What caused the winter drought in western Nepal during recent years? J Clim 26:8241-8256. https://doi.org/10.1175/JCLI-D-12-00800.1

$\mathrm{Xu}$ J, Grumbine RE, Shrestha A et al (2009) The melting Himalayas: cascading effects of climate change on water, biodiversity, and livelihoods. Conserv Biol 23:520-530. https://doi.org/10.1111/j.1523-1739.2009. 01237.x

Yang K, Guyennon N, Ouyang L et al (2018) Impact of summer monsoon on the elevation-dependence of meteorological variables in the south of central Himalaya. Int J Climatol 38:1748-1759. https://doi.org/10. $1002 /$ joc. 5293

Zomer RJ, Trabucco A, Metzger MJ et al (2014) Projected climate change impacts on spatial distribution of bioclimatic zones and ecoregions within the Kailash Sacred Landscape of China, India, Nepal. Clim Chang 125:445-460. https://doi.org/10.1007/s10584-014-1176-2

Publisher's note Springer Nature remains neutral with regard to jurisdictional claims in published maps and institutional affiliations. 